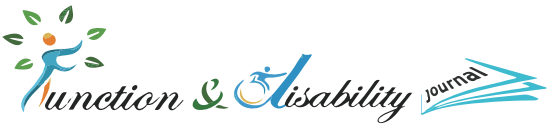

\title{
Narrative Review: \\ Multisensory Stimulation in Dementia
}

\author{
Masoome Zaree ${ }^{\text {* }}$ (iD \\ 1. Department of Occupational Therapy, School of Rehabilitation Sciences, Iran University of Medical Sciences, Tehran, Iran.
}

\section{(c) (i) ()( () ()}

*This work has been published under CC BY-NC-SA 4.0 license.

Article info:

Received: 03 Nov 2020

Accepted: 10 Dec 2020

Available Online: 30 Dec 2020

Funding

This research did not receive any grant from funding agencies in the public, commercial, or non-profit sectors.

Conflict of interest

The authors declare that they have no competing interests.

\section{ABSTRACT}

Background \& Objectives: Dementia is a prevalent disorder around the world. However, its chronic and progressive nature mostly affects physical and psychosocial characteristics and public healthcare. Recently, multisensory interventions have been used in people with dementia as one of the nonpharmacological treatment methods. This narrative review intends to explain multisensory stimulation programs or Snoezelen for those affected with dementia.

Methods: Keywords such as "sensory-based intervention", "sensory stimulation", "sensory processing", "Snoezelen", "sensory modulation", and "dementia" were used in Scopus and PubMed databases with a sensitive search strategy in the articles published between 2000 and 2020.

Results: The initial search retrieved 255 articles. After reviewing and rejecting some duplicates, 65 studies remained in the field of multisensory interventions in dementia. However, only 8 articles fulfilled the inclusion criteria.

Conclusion: Multisensory stimulations in dementia can be used as an adjunctive strategy alongside other therapies. Sensory diets can be applied in common home environments. For this purpose, it is better to use Dunn's sensory processing model. So, along with individual components, context and occupations are also considered.

Keywords: Nervous system disease, Dementia, Sensory deprivation, Review

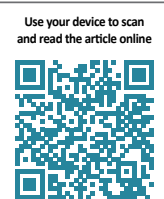

Cite this article as Zaree M. Multisensory Stimulation in Dementia. Function and Disability Journal. 2021; 4:123-130. http:// dx.doi.org/10.32598/fdj.3.19

http://dx.doi.org/10.32598/fdj.3.19

\footnotetext{
* Corresponding Author:
}

\section{Masoome Zaree, PhD candidate.}

Address: Department of Occupational Therapy, School of Rehabilitation Sciences, Iran University of Medical Sciences, Tehran, Iran. Tel: +98 (912) 0477530

E-mail: massomezaree@gmail.com 
A

What is "already known" in this topic:

Recently, multisensory stimulation has become an alternative first-line approach in the treatment of dementia's behavioral and psychological symptoms.

$\rightarrow$ What this article adds:

Multisensory stimulations in dementia can be used as an adjunctive strategy alongside other therapies. In everyday home environments, sensory diets can be applied; for this purpose, it is better to use Dunn's sensory processing model. In this condition, besides individual components, context and occupations are also considered.

\section{Introduction}

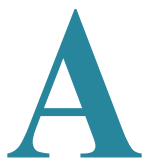

ing is an inevitable physical and physiological phenomenon. Like other nations, the Iranian population is also becoming old. Statistics show that the number of older people in Iran increased 4.4 times from 1957 to 2007 . The increase in the elderly population causes economic, social, and health problems [1]. One of the problems that affect people in old age is cognitive impairment, which causes extensive functional limitations. One of the most critical public health problems in our society is dementia. It is widespread in the elderly, without effective treatments, along with a high functional and cognitive dependency [2]. According to a study conducted in Iran in 2016, the prevalence of dementia among people aged 60-64 years was 3.6\%, in people aged 65-69 years $6.2 \%$, in people aged $70-74$ years $10.4 \%$, in people aged $79-75$ years $14.4 \%$ and in the age group over 80 years $13 \%$. It also seems that the prevalence of dementia in Iran is higher than in other countries [3].

Dementia is a chronic, complex, progressive, and disabling disorder that affects not only the individual but also the family, caregivers, the health care system, and society and puts an economic strain on them. Dementia has been cited as one of the most challenging issues in the health system [4].

Today, society is struggling to care for patients with dementia. There are currently several treatments to stabilize the daily functioning of these people. Although medication has helped reduce some psychiatric symptoms [5], they have a moderate effect in improving behavioral and cognitive symptoms [6]. Various methods have been proposed for the rehabilitation of these people; focusing on sensory problems is one of the new therapies in dementia.
The destruction of temporolimbic structures in people with dementia leads to inability of integrity of sensory information, thus causing behavioral, cognitive and social problems $[7,8]$. Therefore, paying attention to sensory processing problems as an essential component in behavior and participation in daily life activities can help control behavioral problems and functional disabilities [9]. Sensory stimulation is employing various techniques to arouse the senses to raise alertness and reduce agitation. It enhances the quality of life, which is the overall objective of sensory stimulation methods [10].

Two theoretical constructs can explain the multisensory stimulation environment: neurobiological and behavioral. Based on the neurobiological approach, patients in the final stages of dementia may receive too little stimulation or too excessive or inappropriate stimulation (doors slamming or patients screaming).

The Kovach Model of Imbalance in Sensoristasis (MIS) proposes that the disproportions in the sensory stimulation and sensory-calming activities affect instrumental and social functioning. Thus, a multisensory stimulation environment organizes an adequate intervention and delivers a range of activities that can be either sensory-stimulating or calming regarding their effects, depending on the therapeutic needs of the patient. On the other hand, the behavioral position, proposed by the functional analytic multisensory environmental therapy, suggests that the Mini-Mental State Examination (MSSE) delivers the older people with no contingent sensory reinforcement arousing states of reward and the relaxation response [11].

In 2002, Chung and colleagues in a systematic review examined the clinical efficacy of Snoezelen (or multisensory stimulation) for older people with dementia and their caregivers. It was concluded that Snoezelen had become a commonly-used intervention to manage maladaptive behaviors and to promote the positive mood of 
older people with dementia. Still, more studies are needed to select the best protocol to present the multisensory interventions [12].

This study aimed to review studies on multisensory interventions in dementia as a narrative review and select the best structure for future studies.

\section{Materials and Methods}

This study was performed to review studies related to multisensory interventions in people with dementia in 2020.

\section{Search strategy}

Keywords such as "sensory-based intervention", "sensory stimulation", "sensory processing”, "Snoezelen”, "sensory modulation", and "dementia" were used in Scopus and PubMed databases with a sensitive search strategy (2000- July 2020).

\section{Types of study to be included}

Randomized controlled trials (RCTs) studied Snoezelen or multisensory stimulation programs as an intervention for people with dementia.

Staff members or researchers should deliver the sensory-based intervention to individuals with dementia (e.g. Snoezelen, music therapy, massage/touch, phototherapy, physical activity, social interaction, sensory garden, aromatherapy, pet therapy).

By examining 255 articles, 65 articles are found related to sensory processing in dementia. Still, based on this study, 8 articles were chosen to describe the Snoezelen for people with dementia.

\section{Results}

The initial search retrieved 255 articles. After reviewing and rejecting some similar studies, 65 studies were remained in the field of multisensory interventions in dementia. However, only 8 articles fulfilled the inclusion criteria (Figure 1). Table 1 summarized the study results.

\section{Participants}

The study participants were predominantly 65 years and older, with a medical diagnosis of moderate-to-severe dementia. Sample sizes of the articles range from 19 to 136.

\section{Snoezelen}

Eight studies were identified that examined Snoezelen as their intervention procedure. Snoezelen room contains elements like water bubble columns within mirrors, alternating-color fiber-optic cables, water bed, an interactive projecting system, rotating mirror ball with color light projector, video, aromatherapy equipment with fragrant oils,

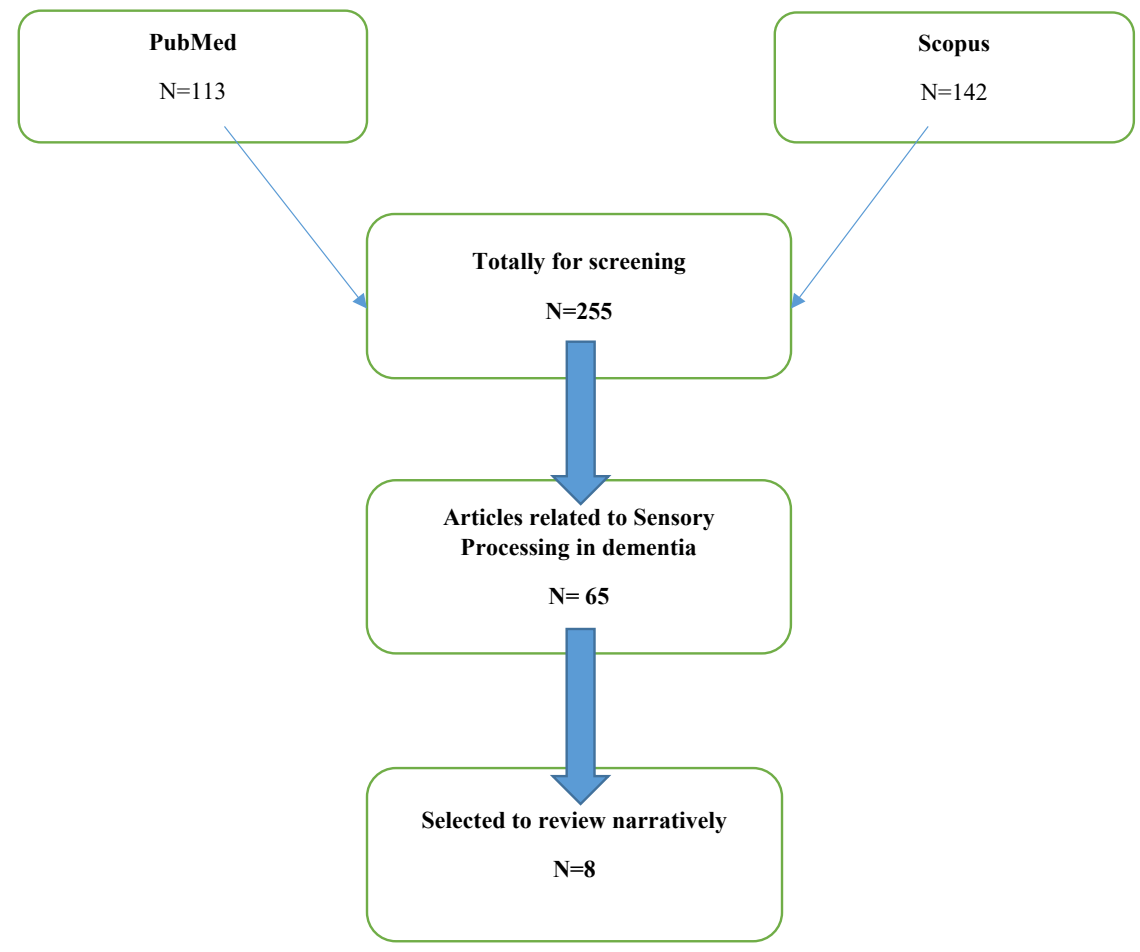

Figure 1. Included studies 
Table 1. Summary of included studies

\begin{tabular}{|c|c|c|c|c|c|c|c|c|}
\hline 衣 & $\begin{array}{l}\text { Sanchez et al. } \\
\text { (2016) [11] }\end{array}$ & $\begin{array}{l}\text { Collier et al. } \\
(2010)[18]\end{array}$ & $\begin{array}{l}\text { Klages et al. } \\
(2011) \text { [19] }\end{array}$ & $\begin{array}{l}\text { Maseda et al. } \\
(2018)[15]\end{array}$ & $\begin{array}{l}\text { Roumen et } \\
\text { al. (2008) } \\
{[22]}\end{array}$ & $\begin{array}{l}\text { Baillon et al. } \\
\text { (2004) [14] }\end{array}$ & $\begin{array}{l}\text { Baker et al. } \\
(2001)[16]\end{array}$ & $\begin{array}{c}\text { Baker, et al., } \\
2003[17]\end{array}$ \\
\hline$z$ & 22 & 30 & 19 & 21 & 21 & 20 & 33 & 136 \\
\hline 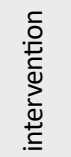 & $\begin{array}{l}\text { Multisensory } \\
\text { stimulation } \\
\text { environment } \\
\text { (MSSE) }\end{array}$ & $\begin{array}{l}\text { Multisensory } \\
\text { environment } \\
\text { (MSE) }\end{array}$ & $\begin{array}{l}\text { Snoezelen } \\
\text { room }\end{array}$ & $\begin{array}{l}\text { Multisensory } \\
\text { stimulation } \\
\text { environment } \\
\text { (MMSE) }\end{array}$ & Snoezelen & Snoezelen & $\begin{array}{l}\text { Multisensory } \\
\text { stimulation }\end{array}$ & $\begin{array}{l}\text { Multisen- } \\
\text { sory stimu- } \\
\text { lation }\end{array}$ \\
\hline 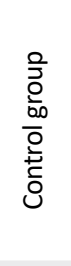 & $\begin{array}{l}\text { Individualized } \\
\text { music sessions }\end{array}$ & Gardening & $\begin{array}{l}\text { Control } \\
\text { group } \\
\text { participants } \\
\text { received } \\
\text { an equal } \\
\text { amount of } \\
\text { volunteer } \\
\text { visits }\end{array}$ & $\begin{array}{l}\text { Individualized } \\
\text { music sessions }\end{array}$ & Usual care & $\begin{array}{l}\text { Reminis- } \\
\text { cence } \\
\text { therapy }\end{array}$ & Activity & Activity \\
\hline $\begin{array}{l}\stackrel{c}{0} \\
\frac{0}{0} \\
\frac{0}{0}\end{array}$ & $\begin{array}{l}\text { Two } 30-\text { min } \\
\text { weekly ses- } \\
\text { sions over } 16 \\
\text { weeks }\end{array}$ & $\begin{array}{l}\text { Three sessions } \\
\text { over } 4 \text { weeks }\end{array}$ & $\begin{array}{c}\text { Twice a } \\
\text { week for } 6 \\
\text { weeks }\end{array}$ & $\begin{array}{l}\text { Two-weekly } \\
\text { sessions lasted } \\
30 \text { minutes for } \\
12 \text { weeks }\end{array}$ & $\begin{array}{c}\text { Three } \\
\text { Snoezelen } \\
\text { sessions per } \\
\text { week for } 12 \\
\text { weeks }\end{array}$ & $\begin{array}{l}\text { Three ses- } \\
\text { sions each } \\
\text { of Snoezelen } \\
\text { and reminis- } \\
\text { cence }\end{array}$ & $\begin{array}{c}\text { Eight } \\
\text { standardized } \\
\text { MSS sessions } \\
\text { and activity } \\
\text { sessions }\end{array}$ & $\begin{array}{l}\text { Eight } \\
\text { 30-minute } \\
\text { sessions } \\
\text { over } 4 \\
\text { weeks }\end{array}$ \\
\hline 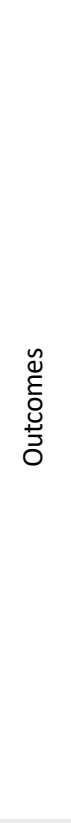 & $\begin{array}{c}\text { Agitation } \\
\text { (Cohen-Mans- } \\
\text { field Agitation } \\
\text { Inventory, } \\
\text { CMAI) mood } \\
\text { (Cornell Scale } \\
\text { for Depression } \\
\text { in Dementia, } \\
\text { CSDD) anxiety } \\
\text { (Rating Anxiety } \\
\text { in Dementia, } \\
\text { RAID) Cogni- } \\
\text { tive function } \\
\text { (Severe Mini- } \\
\text { Mental State } \\
\text { Examination, } \\
\text { SMMSE) The } \\
\text { severity of de- } \\
\text { mentia (Bed- } \\
\text { ford Alzheimer } \\
\text { Nursing } \\
\text { Severity Scale, } \\
\text { BANS-S) }\end{array}$ & $\begin{array}{l} \\
\text { Degree of } \\
\text { physical } \\
\text { inactivity, } \\
\text { intellectual } \\
\text { impairment, } \\
\text { emotional } \\
\text { and cognitive } \\
\text { impairment } \\
\text { (Gottfries- } \\
\text { Brane-Steen } \\
\text { scale, GBS) } \\
\text { Functional } \\
\text { Performance } \\
\text { (Assessment } \\
\text { of Motor and } \\
\text { Process Skills, } \\
\text { AMPS) }\end{array}$ & $\begin{array}{l}\text { Func- } \\
\text { tional Reach } \\
\text { Test, the } \\
\text { eyes-open } \\
\text { Sharpened } \\
\text { Romberg, } \\
\text { Timed Up } \\
\text { and Go Test } \\
\text { with and } \\
\text { without } \\
\text { dual-task, } \\
\text { Falls fre- } \\
\text { quencies }\end{array}$ & $\begin{array}{l}\text { Mood, Speech, } \\
\text { Relating } \\
\text { to people, } \\
\text { Relating to } \\
\text { the environ- } \\
\text { ment, Need } \\
\text { for prompting, } \\
\text { Stimulation } \\
\text { level (INTER- } \\
\text { ACT SHORT) }\end{array}$ & $\begin{array}{c}\text { Daily } \\
\text { observa- } \\
\text { tion scales } \\
\text { (DOS), Clini- } \\
\text { cal Global } \\
\text { Impres- } \\
\text { sion-Im- } \\
\text { provement }\end{array}$ & $\begin{array}{l}\text { Cognitive } \\
\text { impairment } \\
\text { (Mini- } \\
\text { Mental State } \\
\text { Examina- } \\
\text { tion, MMSE) } \\
\text { Dementia } \\
\text { sever- } \\
\text { ity (Clinical } \\
\text { Dementia } \\
\text { Rating Scale } \\
\text { (CDRS)) } \\
\text { Agitated } \\
\text { behavior } \\
\text { (Cohen- } \\
\text { Mansfield } \\
\text { Agitation } \\
\text { Inventory- } \\
\text { short Form) } \\
\text { Heart rate } \\
\text { (heart-rate } \\
\text { monitor) } \\
\text { Mood and } \\
\text { behavior } \\
\text { (INTERACT } \\
\text { Scale) }\end{array}$ & $\begin{array}{l}\text { Behavior } \\
\text { (REHAB } \\
\text { BMD Scale) } \\
\text { Mood (The } \\
\text { Behavior } \\
\text { and Mood } \\
\text { Disturbances } \\
\text { Scale (BMD)) } \\
\text { Cognition } \\
\text { (MMSE) }\end{array}$ & $\begin{array}{c}\text { Behavior } \\
\text { (Behavior } \\
\text { Rating } \\
\text { Scale, RE- } \\
\text { HAB Scale) } \\
\text { Cognition } \\
\text { (Mini- } \\
\text { Mental } \\
\text { Status Ex- } \\
\text { amination) } \\
\text { Mood (The } \\
\text { Behavior } \\
\text { and Mood } \\
\text { Disturbance } \\
\text { Scale, BMD) }\end{array}$ \\
\hline $\begin{array}{l}\frac{+}{5} \\
\stackrel{⿹}{\longleftarrow}\end{array}$ & $\begin{array}{l}\text { MSSE could } \\
\text { have better } \\
\text { effects on anxi- } \\
\text { ety symptoms } \\
\text { and dementia } \\
\text { severity in } \\
\text { comparison } \\
\text { with individu- } \\
\text { alized music } \\
\text { sessions in el- } \\
\text { derly patients } \\
\text { with severe } \\
\text { dementia }\end{array}$ & $\begin{array}{l}\text { Results indi- } \\
\text { cate significant } \\
\text { improvement } \\
\text { in functional } \\
\text { performance } \\
\text { in both the } \\
\text { MSE and the } \\
\text { control activ- } \\
\text { ity. Findings } \\
\text { support the } \\
\text { use of MSEs } \\
\text { as a strategy } \\
\text { for enhanc- } \\
\text { ing functional } \\
\text { performance } \\
\text { in dementia }\end{array}$ & $\begin{array}{l}\text { There } \\
\text { were no } \\
\text { significant } \\
\text { changes } \\
\text { in the bal- } \\
\text { ance test } \\
\text { scores and } \\
\text { falls rates } \\
\text { frequency } \\
\text { within } \\
\text { groups } \\
\text { overtime, } \\
\text { or between } \\
\text { the inter- } \\
\text { vention } \\
\text { versus the } \\
\text { control } \\
\text { group }\end{array}$ & $\begin{array}{l}\text { Both interven- } \\
\text { tions seem to } \\
\text { be effective } \\
\text { at managing } \\
\text { mood and } \\
\text { behavioral } \\
\text { disturbances in } \\
\text { the short term } \\
\text { and at improv- } \\
\text { ing physiologi- } \\
\text { cal rates }\end{array}$ & $\begin{array}{l}\text { MSS may } \\
\text { be a useful } \\
\text { addition to } \\
\text { the care of } \\
\text { elderly pa- } \\
\text { tients with } \\
\text { dementia. }\end{array}$ & $\begin{array}{l}\text { This research } \\
\text { has not } \\
\text { shown that } \\
\text { Snoezelen } \\
\text { is more } \\
\text { beneficial for } \\
\text { people with } \\
\text { dementia } \\
\text { than one-to- } \\
\text { one } \\
\text { themed } \\
\text { reminis- } \\
\text { cence. }\end{array}$ & $\begin{array}{l}\text { Both MSS } \\
\text { and Activity } \\
\text { sessions ap- } \\
\text { pear to be } \\
\text { effective and } \\
\text { appropriate } \\
\text { therapies for } \\
\text { people with } \\
\text { dementia. }\end{array}$ & $\begin{array}{l}\text { Overall, } \\
\text { MSS was } \\
\text { found to } \\
\text { be no more } \\
\text { effective } \\
\text { than an } \\
\text { activity in } \\
\text { changing } \\
\text { the behav- } \\
\text { ior, mood, } \\
\text { or cognition } \\
\text { of patients } \\
\text { with } \\
\text { dementia in } \\
\text { the short or } \\
\text { long-term }\end{array}$ \\
\hline
\end{tabular}


musical selections, tactile boards with various textures, eye tracking, and head moving activities, and vibrating shoes and pillows. The patients were offered visual, auditory, tactile, and olfactory stimulation, and the therapists adopted a nondirective, enabling approach, encouraging patients to engage with sensory stimuli of their choice.

\section{Outcomes}

The targets were agitation $[13,14]$, mood [13-17], cognitive function $[13,14,16,17]$, anxiety [13], emotional impairment [18], intellectual impairment [18], functional performance [18], falls frequencies [19], speech [15], relating to environment, relating to people, stimulation level, need for prompting [15], dementia severity [13, $14]$, behavior $[14,16,17]$ and heart rate [14].

\section{Discussion}

Multisensory stimulation is a nonpharmacological therapy used in older adults with dementia. The treatment is based on a nondirective approach, not focusing on cognitive stimulation, but encouraging older people to engage with sensory stimuli of their choice. In other words, its use is based on the biopsychosocial model, as neuropsychiatric symptoms are affected both by the disease and the physical and psychosocial environment surrounding the elderly [11].

According to the obtained studies, multisensory interventions did not significantly affect behavior, mood, or cognition than the interventions presented to the control group Baker et a1. (2003) [17]. But, In the study of Sanchez et al. (2016) [13], which aimed to investigate the effect of multisensory interventions and individualized music sessions, multisensory interventions were found to have a better impact on anxiety symptoms and dementia severity. Also, Collier et al. (2010) [18] recommended using this intervention for improving functional performance. In the study of Klages et al. (2011) [19], no significant changes were seen in balance test scores and falling rates within groups over time or between the intervention versus the control group. Maseda et al. (2018) [15] has also stated that both interventions (multisensory stimulation and music sessions) are effective at managing mood and behavioral disturbances in the short term and improve physiological rates. Baillon et al. (2004) [14] concluded that multisensory stimulations may be a valuable supplementary in treating elderly patients with dementia.

All studies have used almost the same intervention structure to provide sensory stimulation) in the results section, the structure of the Snoezelen room is mentioned in detail ). Of course, there are differences in the control groups; for example, in Sánchez, Maseda et al. (2016) and Maseda, Cibeira et al. (2018), individualized music sessions, in Baker, Holloway et al. (2003) and Baker, Bell et al. (2001) activity session, and in Baillon, Van Diepen et al. (2004) the reminiscence therapy have been used. Other studies have used the usual care. In most studies, behavior, cognition, and mood are considered the main outcome measures, but in Collier and Klages studies, functional performance, level of physical activity, falling, etc., are considered. The study of Baker, Holloway et al. (2003) has a higher sample size than the other 7 studies and is known as one of the most critical studies in the field of sensory stimulation.

Multisensory environments dominate sensory stimulation practice for people with dementia. These distinct environments with specific equipment stimulate sight, hearing, and touch in time-bound sessions [12]. Currently, limited evidence is available for whole day sensory diets for people with dementia. Studies usually have pragmatically focused on session-based interventions with defined time and location boundaries to control variables for gathering transferable positivist evidence. This method limits the evidence base of sensory stimulation to similarly prescriptive practice. Dunn's Model of sensory processing supports a whole day 'sensory diet' approach [20] and agrees with Ayres' Model of sensory integration (1979). This person-centered and creative approach may be applied to social care contexts worldwide, using local resources as appropriate for people's occupational lives [21].

Previous studies have used multisensory stimulation in a variety of ways, these studies have focused on the functional components of the individual and tried to change and improve them, but the match between the individual, occupation, and context have not been considered. The presented interventions are not adequately structured and formulated according to a specific framework or program. Also, these interventions are sessionbased (participation in specific treatment sessions during the week), and intervention strategies are not provided to caregivers. The results of previous studies have shown that session-based interventions have a short-term effect on behavior, mood, and cognition; therefore, it has been suggested that in order to have a long-term impact on multisensory interventions, it is better to train interventions to caregivers (not limited to one treatment session) and integrated with daily life activities. 


\section{Conclusion}

Multisensory stimulations in dementia can be used as an adjunctive strategy alongside other therapies. Sensory diets can be implemented in everyday home environments. For this purpose, it is better to use Dunn's sensory processing model so that in addition to individual components, context, and occupations are also considered.

\section{Ethical Considerations}

\section{Compliance with ethical guidelines}

There were no ethical considerations to be considered in this research.

Funding

This research did not receive any grant from funding agencies in the public, commerical, or non-profit sectors.

\section{Conflict of interest}

The author declared no conflict of interest

\section{References}

[1] Allahyari E, Keramati M, Kamali M. [Predicting elderly depression prevalence in different Iranian ethnicities and associated factors (Persian)]. Salmand: Iran J Ageing. 2020; 15(1):118-29. [DOI:10.32598/ sija.2020.3.130]

[2] Kasper D, Braunwald E, Hauser E, Longo D, Jameson L, Fauci A. Harrison's principles of internal medicine. New York: The McGraw-Hill Companies; 2005. https://books.google.com/ books?id=7gxjMV8hClsC\&q=

[3] Sharifi F, Fakhrzadeh H, Varmaghani M, Arzaghi SM, Khoei MA, Farzadfar F, et al. Prevalence of dementia and associated factors among older adults in Iran: National Elderly Health Survey (NEHS).Arch Iran Med. (2016); 19(12):838-4. http://www.aimjournal.ir/Article/1100

[4] Kalaria RN, Maestre GE, Arizaga R, Friedland RP, Galasko D, Hall $\mathrm{K}$, et al. Alzheimer's disease and vascular dementia in developing countries: prevalence, management, and risk factors. Lancet Neurol. 2008; 7(9):812-26. [DOI:10.1016/S1474-4422(08)70169-8]

[5] Sutton AL. Alzheimer Disease Sourcebook (Health Reference) Detroit: Omnigraphics Inc; 2011. https://www.amazon.com/Alzheimer-Disease-Sourcebook-Health-Reference/dp/078081150X

[6] Kathryn Oliphant MA. The 36-hour day; A family guide to caring for people with Alzheimer disease other dementias, and memory loss in later life. Care Manage J. 2007; 8(4):222-4. https://search.proquest. com/docview/197981377?pq-origsite=gscholar\&fromopenview=true

[7] Amanzio M, Vase L, Leotta D, Miceli R, Palermo S, Geminiani G. Impaired awareness of deficits in Alzheimer's Disease: The role of everyday executive dysfunction. J Int Neuropsychol Soc. 2013; 19(1):63-72. [DOI:10.1017/S1355617712000896] [PMID]

[8] Russo-Neustadt A. Adrenergic receptors in Alzheimer's disease brain: Selective increases in the cerebella of aggressive patients J Neurosci. 1997; 17(14):5573-80. [DOI:10.1523/JNEUROSCI.17-14-05573.1997] [PMID] [PMCID]

[9] Jerome EM, Liss M. Relationships between sensory processing style, adult attachment, and coping. Pers Individ Dif. 2005; 38(6):1341-52. [DOI:10.1016/j.paid.2004.08.016]

[10] Lykkesle E, Gjengedal E, Skrondal T, Storjord MB. Sensory stimulation - a way of creating mutual relations in dementia care. Int $J$ Qual Stud Health Well-being. 2014; 9(1):23888. [DOI:10.3402/qhw. v9.23888] [PMID] [PMCID]

[11] Sánchez A, Millán-Calenti JC, Lorenzo-López L, Maseda A. Multisensory stimulation for people with Dementia: A review of the literature. American Journal of Alzheimer's Disease \& Other Dementiasr. 2013; 28(1):7-14. [DOI:10.1177/1533317512466693] [PMID]

[12] Chung JC, Lai CK. Snoezelen for dementia. Cochrane Database Syst Rev. 2002; (4):Cd003152. [DOI:10.1002/14651858. CD003152] [PMID]

[13] Sánchez A, Maseda A, Marante-Moar MP, de Labra C, LorenzoLópez L, Millán-Calenti JC. Comparing the effects of multisensory stimulation and individualized music sessions on elderly people with severe dementia: A randomized controlled trial. J Alzheimers Dis. 2016; 52(1):303-15. [DOI:10.3233/JAD-151150] [PMID]

[14] Baillon S, Van Diepen E, Prettyman R, Redman J, Rooke N, Campbell R. A comparison of the effects of Snoezelen and reminiscence therapy on the agitated behaviour of patients with dementia.Int J Geriatr Psychiatry. 2004; 19(11):1047-52. [DOI:10.1002/gps.1208] [PMID]

[15] Maseda A, Cibeira N, Lorenzo-López L, González-Abraldes I, Buján A, de Labra C. Multisensory stimulation and individualized music sessions on older adults with severe dementia: Effects on mood, behavior, and biomedical parameters. J Alzheimers Dis 2018; 63(4):1415-25. [DOI:10.3233/JAD-180109] [PMID]

[16] Baker R, Bell S, Baker E, Holloway J, Pearce R, Dowling Z, et al A randomized controlled trial of the effects of Multisensory Stimulation (MSS) for people with dementia. Br J Clin Psychol. 2001; 40(1):81-96. [DOI:10.1348/014466501163508] [PMID]

[17] Baker R, Holloway J, Holtkamp CC, Larsson A, Hartman LC, Pearce R, et al. Effects of multisensory stimulation for people with dementia. J Adv Nurs. 2003; 43(5):465-77. [DOI:10.1046/j.13652648.2003.02744.x] [PMID]

[18] Collier L, McPherson K, Ellis-Hill C, Staal J, Bucks R. Multisensory stimulation to improve functional performance in moderate to severe dementia-interim results. Am J Alzheimer's Dis Other Dementiasr 2010; 25(8):698-703. [DOI:10.1177/1533317510387582] [PMID]

[19] Klages K, Zecevic A, Orange JB, Hobson S. Potential of snoezelen room multisensory stimulation to improve balance in individuals with dementia: a feasibility randomized controlled trial. Clin Rehabil. 2011; 25(7):607-16. [DOI:10.1177/0269215510394221] [PMID]

[20] Brown C, Dunn W. Adolescent-adult sensory profile: User's manual. Bloomington: Therapy Skill Builders; 2002. https://books. google.com/books?id=-JhrPgAACAAJ\&dq=

[21] Haigh J, Mytton C. Sensory interventions to support the wellbeing of people with dementia: A critical review. British J Occup Ther. 2015; 79(2):120-6. [DOI:10.1177/0308022615598996] 
مدالخالات منّد حسى در دمانس: مرور حكايتى

(i) " معصومه زارعى

1. كروه آموزشي كاردرماني، داتشكده علوم توانبخشي، دائشكاه علوم بزُشكى ايران، تهران، ايران.

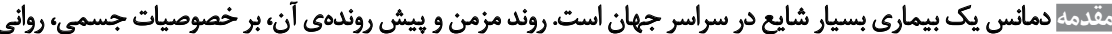

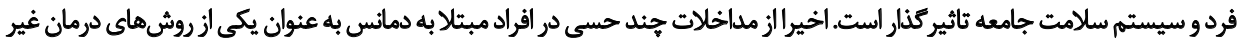

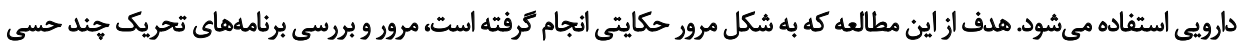

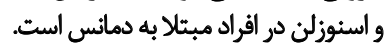

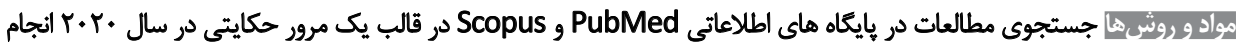

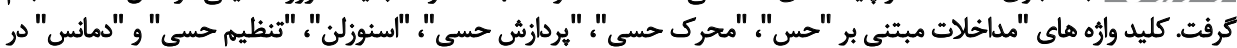

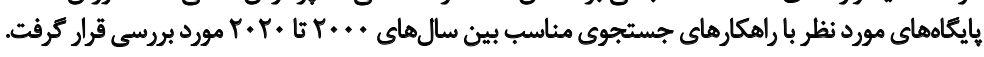

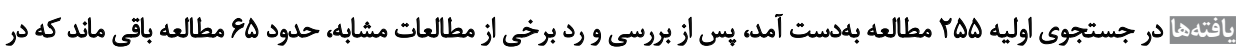

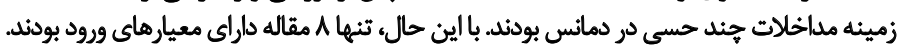

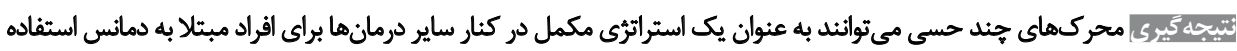

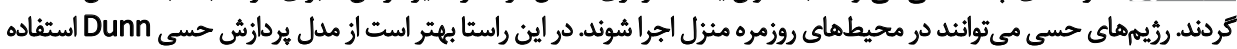

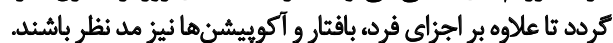

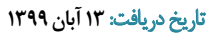

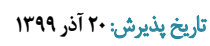

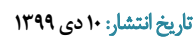


This Page Intentionally Left Blank 